\section{Safety of the Pill}

SIR,-As a busy physician, writing a letter to your correspondence column is provoked only by a rare event-by profound indignation, even disgust. Quite by chance, on 21 April I switched on to B.B.C. "World at One" and heard $\mathrm{Mr}$. Hardcastle introduce Dr. Caroline Deys, wife of Dr. Malcolm Potts (Medical Secretary of the International Planned Parenthood Federation) and herself also concerned with family planning, who claimed that to emphasize the harmlessness of oral contraceptives, she had intermittently given the Pill to her twoyear-old daughter.

I am myself working in the family planning movement and prescribe the Pill for patients when indicated, and while I have no desire to enter the controversy between pill pushers and abolitionists, the presentation and style of such programmes degrade the medical profession. What Dr. Deys is doing is neither justifiable nor comprehensible, whether as a physician, a mother, or one who is seriously concerned with contraception. What adults do after discussion with their medical advisers is one thing, but to give to an infant potent drugs for nontherapeutic purposes is contrary to medical practice, particularly in view of the well documented effects of synthetic steroids on gonadal function, especially in the neonate..$^{1-5}$ It isn't a question of the number of pills the child was given, but the ethical principle involved.

Isn't it time that the public heard other than extreme views, and that in matters of such magnitude and importance as the contraceptive pill, the well informed "middle of the roader" is heard pro bono publico? What has happened to the suggestions that without withdrawing the Pill we should undertake studies of its action which would produce results in a shorter period of time, so that we could produce a safer Pill and not iust wait for the statistical computation of side effects? As one of these workers recently said this is essentially an organizational problem for "we are seriously under-utilising already available techniques of investigating the direct effects of all drugs-including the Pill-on the tissues". "Innovation is difficult in our conservative profession. Man requires a challenge if he is to conquer new horizons, and the way we are going about the Pillclinically and scientifically-is not a challenge. All we are doing at present is "Waiting for Godot."-I am, etc.,

London $\mathbf{W} .1$

JEAN INFIELD.

\section{References}

1 Saunders, F. J., Endocrinology, 1966, 80, 447. Rogica (Kb.), 1966 , Suppl., 105.
Carr, D. H., Lancet, 1967,' $2,830$.

4 Williams, D., Lancet, 1967, 2, 830. A. A., Nature, 1968, 220, 1145 .
Beaconsfield, P., and Ginsburg, J., Lancet, 1968, 5 Beaconsfield, P., and Ginsburg, J., Lancet, 1968,
1, 592.
6 Beaconsfield, P., Medical News Tribune, 1969, Beacons
$1,8$.

SIR,-No wonder the English women are confused. I feel sorry for them.

In transit through London I read in your Daily Mirror, Tuesday 22 April, the front page headline "The doctor who gives her baby birth pills to prove that the drug is harmless." One day later the Evening News carries front page headline "Danger drug warning; birth pill-a disturbing new report." And on the same day the Evening Standard carries a front page headline "New-style pill saving lives."

In more than 10 years of Pill use in the United States I do not recall on a single occasion front page headlines of this type in any newspaper. In Britain there is obviously a fault somewhere down the line of communication.-I am, etc.,

Chicago, IIl., U.S.A.

M. SCHWARZ.

SIR,-It is reported on radio ("World a One" 21 April) and in the lay press (The Times, 22 April) that a doctor has administered contraceptive pills to her daughter aged two years to prove that the Pill is safe.

If the reports are correct, will she explain to members of her profession the scientific basis of her belief? In my view, the test proves nothing, except possibly one thing, which I forbear to mention.-I am, etc.,

London S.W.3.

Clive Shields.

\section{Profession-or Trade?}

SIR,- - The true service of a doctor is neither to a consultant nor to a board, but to his patient, whose best interest can never be served with one eye on the clock and the other on the pay packet." How cheering to read this sentence in the letter from Dr. E B. Nye (25 April, p. 234), and the fact that he qualified as recently as 1964 is an added cause for pleasure and hope for the future. It is quite certain that clinical medicine cannot be practised with real satisfaction to patient or practitioner if it is to be governed by rigid rules and regulations as to normal hours of duty, overtime, etc.

I believe that the great majority of hospital doctors of all grades realise and accept this and will apn!aud Dr. Nye's statement as I do. Unfortuna:ely there is a small minority, of whom I have had recent experience, who already try to practise according to their contractual rights rather than to a sense of responsibility and service to their patient, and I can vouch for the allround dissatisfaction which results. This minority may be encouraged and perhaps increased by the new contracts to be offered to hospital junior doctors and the regulations about overtime pay.--I am, etc.,

Ipswich.

BERNARD IUBY.

SIR,-At a recent meeting the junior medical staff of this hospital discussed the proposals for extra duty allowance for junior hospital staff. 'Circular B/D112/039).

Strong objection was taken to the idea of clocking on and off for so called "out of time" work; the concept is repugnant, and the practice cumbersome and open to abuse. Above all, it was asked, who is to decide what work is voluntary and what compulsory? The consultant or the administrator? A fair amount of work done by a good houseman could well be termed "voluntary" in that it is not strictly necessary or easily tangible, while at the same time being of supreme value in the well running of his wards and the overall wellbeing of his patients.

At present there is no easy solution to the long hours worked by many hospital junior doctors. The obvious one, to increase the complement of junior staff where on-call hours are excessive, would solve the shortterm problem but at the same time would tighten the already constricted registrar consultant bottleneck. Loading the salary to suit certain "designated" jobs as was suggested by Dr. D. A. Chamberlain and others (11 April, p. 115) is the best shortterm solution, but it must never be forgotten that it is wrong for any hospital doctor to be on duty for more than one hundred hours a week and paying him for being so will not make it right.

Any alternative to a salaried service is unacceptable; the immediacy of extra cash for extra hours worked may be superficially attractive but in the long run will surely tarnish us. The present proposals for overtime work can at best be no more than a stop-gap, and if they are not thrown out now they will remain as a permanent insult to our professionalism.-I am, etc.,

W. A. Bliss, Chairman, Junior Medical Staff Committee,
Basingstoke and District Hospital.
Basingstoke, Hants.

SIR,-The Department of Health and Social Security has sent a document, B/D112/039 dated 24 March, 1970, to the secretaries of regional hospital boards, boards of governors, and hospital management committees concerning proposals for extra duty payments for hospital junior staff. Details of this document were recently made known to the hospital junior staff of the Westminster Hospital teaching group who met to discuss these proposals on 21 April, 1970. The following proposal was carried by a very large majority:

"This meeting proposes that the Department of Health and Social Security's plans for extra duty payment should be rejected, and that further consideration be given to a salary for hospital junior staff consistent with the realization that extra duty may be performed."

It was felt that extra duty payments would have no short term advantages to hospital junior doctors and would ultimately be damaging to the profession as a whole.I am, etc.,

Westminster Hospital,
London S.W.1.

P. C. Weaver.

\section{Search for the Non-Euphoric Analgesic}

SIR,-While one appreciates the need for the up-dating of drug laws, and for energetic investigation of the reefer problem in schools, it would seem wishful thinking to assume that one can discover really effective analgesics that are going to be completely non-addictive-Dr. T. S-B Kelly (28 March, p. 819).

As students, we were sung the praises of pethidine as non-habit forming, and within a few months one heard of anaesthetists and midwives falling for it. 